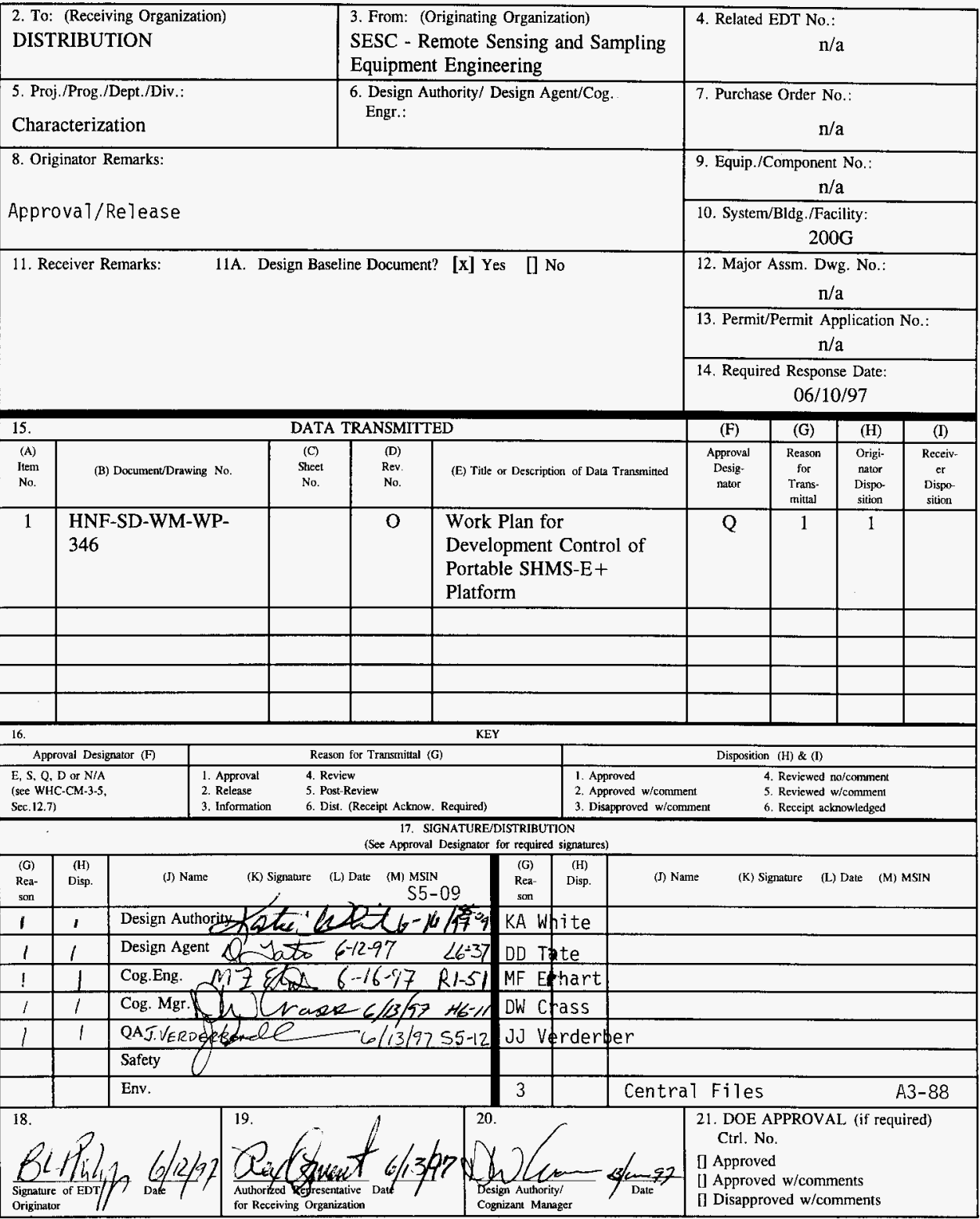




\section{WORK PLAN FOR THE DEVELOPMENTAL CONTROL OF PORTABLE SHMS-E+ PLATFORM}

\section{B. L. Philipp}

SGN Eurisys Services Corporation, Richland. WA 99352

U.S. Department of Energy Contract DE-AC06-87RL10930

$$
618424
$$

EDT/ECN: No. G19500 /s UC: 2030

Org Code: UC200000 Charge Code: N2047

B\&R Code: EW3120072 Total Pages: $-z_{j \beta}$

Key Words: Standard Hydrogen Monitoring System (SHMS)

Abstract:

This document describes the Developmental Control process to be used by Dyncorp Fabrication Services and SGN Eurisys

Services Corporation - Remote Sensing and Sampling Equipment

Engineering (RSSE) in the fabrication of two portable SHMS-

E+ Platforms for Lockheed Martin Hanford (TWRS).

TRADEMARK DISCLAIMER. Reference herein to any specific commercial product, process, or service by trade name. trademark. manufacturer, or otherwise, does not necessarily constitute or imply its endorsement. recommendation, or favoring by the United States Government or any agency thereof or its contractors or subcontractors

Printed in the United States of America. To obtain copies of this document, contact: WHC/BCS Document Control Services. P.0. Box 1970. Mailstop H6-08, Richland WA 99352. Phone (509) 372-2420: Fax (509) 376-4989
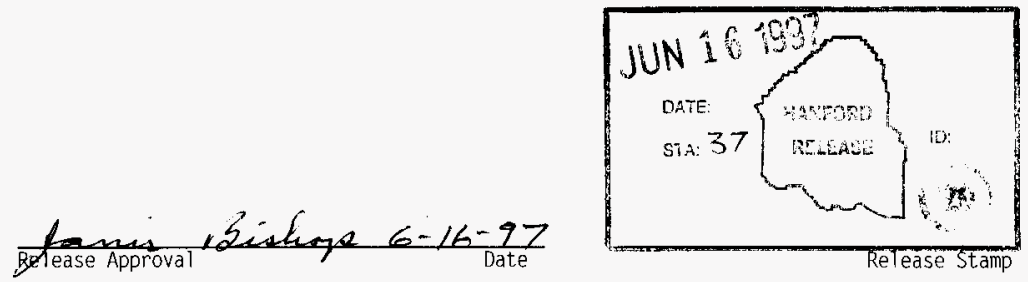

\section{Approved for Public Release}




\section{WORK PLAN FOR THE DEVELOPMENTAL CONTROL OF PORTABLE SHMS-E + PLATFORM SKID FABRICATION}

\subsection{INTRODUCTION}

During the fiscal year 1997, Dyncorp Fabrication shops/200 West area shall fabricate two skids for two portable SHMS platforms with all items deemed "facility use potential." This work plan identifies the drawings already defined by Remote Sensing and Sampling Equipment Engineering (RSSE), and the planned engineering tasks to be performed by RSSE engineers, in coordination with Dyncorp Fabrication Services, during the planning and fabrication of skids described here.

\subsection{SCOPE}

\subsection{OBJECTIVE}

The objective is to proceed with the fabrication of two skids which will be used to construct two Portable SHMS-E+ Platforms for facility use potential.

\subsection{DRAWINGS}

The "Development Control" drawing used for this series of fabrications are as follows:

- H-14-102407, Portable Standard-E Hydrogen Monitoring System Platform Assembly.

Sketches will be supplied by the RSSE Cognizant Engineer to serve as guidelines for the drafting of the new Fabrication drawings.

The RSSE Cognizant Engineer or delegate, will be notified if any fabrication planning or floor difficulties arise due to errors or inconsistencies in the above drawings. Also, it is the responsibility of the RSSE engineer to notify Dyncorp Fabrication planners and Fabrication Quality Control if any changes are decided which affect equipment procurement or fabrication. All changes, additions, or deletions to the above drawings shall be completed according to CM-6-1, "Standard Engineering Practices (EP-2.4), Development Control Requirements, Section 2.3.1. which states "changes, additions, or deletions shall be controlled by either marking the changes in "red" or preparing additional pages or sketches and identifying traceability with the affected drawing, sketch, or specification. All changes shall be approved by the cognizant engineer's dated signature next to each change."

\subsection{RESTRICTIONS/SPECIAL CONDITIONS}

\subsection{NONE}

\subsection{WORK ORDER}

\subsection{FABRICATION WORK ORDER}

The Fabrication work will be assigned an "Internal Work Order" number, by the Tank Waste Remediation System - Safety Upgrades Program budget authority. 


\subsection{INSPECTION}

\subsection{INSPECTION OF FABRICATED ASSEMBLIES}

All inspections will be as required by the RSSE cognizant engineer, as specified on the "J-10 attachment for inspections requested," and will be completed according to Dyncorp Fabrication Service QC Inspection Procedures. Weld inspections shall be in accordance with Note 3 of development control drawing H-14-102407.

\subsection{MATERIALS}

Materials for the skids will be procured by Dyncorp Fabrication Services. Material verification will be performed by Dyncorp fabrication Service QC per the J-10 attachment.

\subsection{SPECIAL TESTING REQUIREMENTS}

\subsection{NONE}

\subsection{SAFETY CLASS DESIGNATION}

\subsection{GENERAL SERVICE}

The Portable SHMS-E + Platform has been classified as a non-safety related General Service system. General design and quality assurance requirements for Non-Safety items shall be followed.

\subsection{APPROVAL DESIGNATOR}

\subsection{APPROVAL DESIGNATORS FOR FABRICATION}

The fabrications covered under this Work Plan will be "Q". Both the Tank Farms Quality Control (QC) and Dyncorp Fabrications Service QC will be involved in the planning and completion of these fabrications. The Dyncorp Fabrications Service QC will perform all required inspections. Tank Farm QC will be kept informed of work in progress and can survey if desired.

\subsection{SHIPPING AND HANDLING INSTRUCTIONS}

\subsection{FABRICATION SERVICES}

Dyncorp Fabrication Service will deliver the completed skids per the instructions of the customer which will be delivered under a separate cover letter.

\subsection{DELIVERY}

\subsection{COMPLETION OF FABRICATION}

The intent of this work plan is to complete two skids under budget for fiscal year 1997 with a delivery date of 25 July 97 . Just prior to completion of the first skid, the drawings described will have all comments and changes incorporated, and will be released for publication. At this time it will be possible for DynCorp Fabrication QC to "green tag" the skid. 